American Journal of Agricultural and Biological Sciences 6 (2): 261-266, 2011

ISSN 1557-4989

(C) 2011 Science Publications

\title{
Geographical Information System Techniques for Evaluation of Groundwater Quality
}

\author{
${ }^{1}$ Shahram Ashraf, ${ }^{2}$ Hossein Afshari and ${ }^{3}$ Abdol Ghaffar Ebadi \\ ${ }^{1}$ Department of Soil Science, \\ ${ }^{2}$ Department of Horticulture, \\ Damghan Branch, Islamic Azad University, Damghan, Iran \\ ${ }^{3}$ Department of Biological Sciences, Jouybar Branch, \\ Islamic Azad University, Jouybar, Iran
}

\begin{abstract}
Problem statement: The present paper tries to assess groundwater suitability for irrigation purpose in Damghan plain (5400 ha). Approach: Twenty four water samples were collected from the active wells. Parameters such as Electrical Conductivity (EC), pH, Total Dissolved Solids (TDS), were recorded in the field and major anions and cations $\left(\mathrm{Ca}^{2+}, \mathrm{Mg}^{2+}, \mathrm{K}^{+}, \mathrm{Na}^{+}, \mathrm{CO}^{2-}, \mathrm{HCO}^{3-}, \mathrm{Cl}^{-}, \mathrm{SO}^{2-}\right.$ and $\mathrm{NO}^{3-}$ ) were analyzed in the laboratory. The data of water wells were imported into the GIS software and the different water quality maps were produced using point data. Then Suitability index of groundwater quality determined by overlaying of water quality maps. Results: Suitability index values revealed that the ground water in Amin Abad, Abdi, Abd Abad, Nasr Abad and parts of Shams Abad villages of study area had "Suitable" quality with the suitability index range between 75-100 and therefore can be used for irrigation usage. Suitability index of the groundwater in Hasnie, Gani Abad and parts of Shams Abad villages were "Moderate" quality with the range between 35-70 and Abas Abad, Abir Abad and Shaman villages had "unsuitable" quality and cannot be used for irrigation purposes. In respect of all evaluating criteria, villages of study areas that had "Suitable" and "Moderate" quality could safely be used for longterm irrigation purposes. Conclusion: The present study demonstrated high efficiency for GIS to analyze complex spatial data and groundwater quality suitability.
\end{abstract}

Key words: Geographical Information System (GIS), Electrical Conductivity (EC), damghan plain, Total Dissolved Solids (TDS), groundwater quality, spatial data, irrigation purposes, Residual Sodium Carbonate (RSC), Soluble Sodium Percentage (SSP), Sodium Adsorption Ratio (SAR)

\section{INTRODUCTION}

Demand of groundwater has been increasing day by day for irrigation by bringing more area under cultivation (Hakim et al., 2009). The chemical composition of water is an important factor for domestic or irrigation purposes(Ganapathy and Ernest, 2004) Salinity and Pollution of well water, either from point or non-point sources, has become a thing of health concern both in urban and rural areas (Orebiyi et al., 2010). Features that generally need to be considered for evaluation of the suitability of groundwater quality for irrigation are the EC, SSP, TDS, RSC and SAR. The Most important cation and anion in a ground water resources are $\mathrm{Ca}^{2+}, \mathrm{Mg}^{2+}, \mathrm{Na}^{+}, \mathrm{HCO}^{3-}, \mathrm{Cl}^{-}$and $\mathrm{NO}^{3-}$. Suitability of irrigation water, with respect to salinity, is assessed on the basis of the 'Electrical Conductivity' (EC) or 'specific conductance' of a water sample. Salts in soil or water reduce water availability to the crop and excessive nutrients reduce yield or quality (Tank and Chandel, 2009). Saline conditions restrict the ability of plants to take up water and nutrients, regardless of whether the salinity is caused by irrigation water or soil water which has become saline because of additions of salty water, poor drainage, or a shallow water table. No plants respond to salinity in a similar manner; some crops can produce acceptable yields at much greater soil salinity than others.

Sodic water is water with a high concentration of sodium, relative to the concentration of calcium and magnesium. Sodic water is not the same as saline water (Bauder and Brock, 2001). Sodium adsorbs into cation exchange sites of the soil, which causes aggregates of some soils to break down (disperse), leading to sealing of soil pores and a reduction in permeability to water flow. The tendency for sodium to increase its

Corresponding Author: Shahram Ashraf, Department of Soil Science, Islamic Azad University, Damghan branch, Damghan, Iran Tel: +98-9122312579 Fax: +98-2325243544 
proportion on the cation exchange sites at the expense of other types of cations (primarily calcium and magnesium) is estimated by the Sodium Adsorption Ratio (SAR), which is the ratio of sodium concentration to the concentration of the square root of the average calcium plus magnesium concentration in either irrigation water or the soil solution (Ayers, 1994).

Normally occurring toxic elements in groundwater are $\mathrm{B}, \mathrm{Na}^{+}, \mathrm{Cl}^{-}$and $\mathrm{HCO}^{3-}$. Specific elements in water may be suitable or unsuitable for irrigation. The information on concentrations of some important chemical constituents of water is necessary to assess their suitability for irrigation. The knowledge of irrigation water quality is critical to understand what management changes are necessary for long-term and short-term productivity particularly for crops that are sensitive to changes in quality (Ramakrishnaiah et al., 2009).

GIS can be a powerful tool for developing solutions for water resources problems for assessing water quality, determining water availability, preventing flooding, understanding the natural environment and managing water resources on a local or regional scale. The advent of modern GIS and remote sensing technologies opened the door to the wide application for land evaluation (Ashraf et al., 2010). The GIS, is potential tool for facilitating the generation and use of thematic information, has been applied and analyzed for identification of groundwater quality suitable zones for domestic and irrigation purposes (Karimipour et al., 2004).

\section{MATERIALS AND METHODS}

The study area is geographically located at between $54^{\circ} 21^{\prime} 56.7^{\prime \prime}$ 'E- 54 ؛27'24.1' 'E and 36 ؛ $02^{\prime} 31.6^{\prime \prime}$ 36 ؛ $08^{\prime}-28.5^{\prime \prime} \mathrm{N}$, in the Damghan plain, Semnan province, Iran. The study was conducted during MarDec 2010. The average rainfall was $120 \mathrm{~mm}$, temperature $15-22^{\circ} \mathrm{C}$ and the humidity $55 \%$ respectively. The investigation included 24 wells consisting of deep, shallow that the wells locations recorded through GPS. The water samples were collected after $30 \mathrm{~min}$ of pumping to avoid stagnant and contaminated water. White plastic containers of 1 L capacity were rinsed out 3-4 times with sampling water. Then the containers were filled up to the brim and were immediately sealed to avoid exposure to air (APHA, AWWA, WPCF, 1998).

The containers were labeled for identification and brought to the laboratory. The groundwater samples were analyzed for $\mathrm{pH}$, EC, Total Dissolved Solids (TDS), sodium $\left(\mathrm{Na}^{+}\right)$, potassium $\left(\mathrm{K}^{+}\right)$, calcium $\left(\mathrm{Ca}^{++}\right)$, magnesium $\left(\mathrm{Mg}^{++}\right)$, boron $(\mathrm{B})$, nitrate-nitrogen $\left(\mathrm{NO}^{3-}\right.$ $\mathrm{N})$, sulphate $\left(\mathrm{SO} 4^{2-}\right)$, chloride $\left(\mathrm{Cl}^{-}\right)$and bicarbonate
$\left(\mathrm{HCO}^{3-}\right)$.The $\mathrm{pH}$ and electrical conductance were determined electrometrically. Calcium and magnesium were determined by complex metric titration, whereas potassium and sodium were estimated by flame emission spe45ctrophotometer (Esmail et al., 2009). Sulphate was determined turbid metrically.Bicarbonate was determined by titration method. Chloride was estimated by argent metric titration .Nitrate and boron were determined calorimetrically (Eaton et al., 2005). Sodium Adsorption Ratio (SAR), Soluble Sodium Percentage (SSP) and Residual Sodium Carbonate (RSC) were calculated on the basis of some standard equations. These equations are as follows:

$$
\begin{aligned}
\mathrm{SAR} & =\frac{\mathrm{Na}^{+}}{\sqrt{\frac{\mathrm{Ca}^{2+} \mathrm{Mg}^{2+}}{2}}} \\
\mathrm{RSC} & =\left(\mathrm{Co}^{2-}+\mathrm{HCO}^{-}\right)-\left(\mathrm{Ca}^{2+}+\mathrm{Mg}^{2+}\right) \\
\mathrm{SSP} & =\frac{\text { Soluble. } \mathrm{Na}^{+} \text {concentration }}{\text { TotalCation.concentration }} * 100
\end{aligned}
$$

Different water quality maps are produced using point data like $\mathrm{pH}$, EC, SAR,chlorides, sulphates, nitrates, SSP and TDS by ArcMap Gis software. Inverse Distance Weighted (IDW) approach used in the present study to supply the locational distribution of groundwater constituents. Then Suitability index of groundwater quality determined by overlaying of water quality maps as following formula:

$\mathrm{SI}=\sum \mathrm{ji} \mathrm{Wji} . \mathrm{Xji}$

Where:

$\mathrm{S}=$ Suitability index

wi $=$ Weight of criterion $\mathrm{i}$ and $\mathrm{xi}$ : score of criterion $\mathrm{i}$

Assigning weight of factors (W): The purpose of weighting is to express the importance or preference of each relative factor to the other factor effects on crop yield and growth rate. Expert opinion of crop specialization was very important in this phase. This process was done in ArcGIS through the composite maps of groundwater quality. Table 1 shows weight of quality factors of groundwater.

Calculation of score value for each criterion(X): In this study, the factor maps were ranked according to Saaty's underlying scale with values 1-9 by discussion with local crop specialist. Classes with higher scores are most suitable or preferred. Scores for the other criteria are calculated based on expert and farmer opinions as well as local.

These values are combined with the above overall weight to provide suitability value for each map. 
Suitability levels for each of the factors were defined; these levels were used as a base to construct the criteria maps (one for each factor). The suitability levels were Suitable-S1, Moderately suitable, not suitable. Table 2 shows Suitability index of groundwater quality.

\section{RESULTS}

Dominant cations and anions: The concentrations of $\mathrm{Ca}++, \mathrm{Mg}++\mathrm{Na}+$ and $\mathrm{K}+$ in water samples varied in the ranges of 2.1-6, 0-2.3, 4.5-16, 0.1-0.34 and 0.1-0.34 meq $\mathrm{L}^{1-}$, respectively, which were far below the recommended maximum concentrations. Bicarbonate concentrations in all the samples were found in the range of 4-8.75 meq $\mathrm{L}^{1-}$.

Other minor constituents: Table 3 shows that $\mathrm{pH}$ value of samples (7.33-8.3) indicated very slight alkaline tendency. The upper limit of $\mathrm{NO}^{3-} \mathrm{N}$ and boron in water were $5,0.8 \mathrm{mg} \mathrm{L}^{1-}$, respectively (Table 3). The $\mathrm{Cl}^{-}$content of groundwater samples varied from 4-14.4 meq $\mathrm{L}^{1-}$. The sulphate concentrations were $0-7.6 \mathrm{mg} \mathrm{L}^{1-}$.

Quality assessment as irrigation water: The estimated amounts of TDS ranged from 966.4-4672 mg
$\mathrm{L}^{1-}$ (Table 4). The highest TDS value related to Shaman village and the lowest value related to Shams Abad village. The range of electrical conductivity and the SAR values in the water samples were 1510-7300 $\mu \mathrm{Scm}^{1-}$ and 2.69-8.37, respectively, that the highest SAR value related to Abas Abad village and the lowest value related to Nasr Abad village.

Table 1: Water quality parameters and assigned unit weights

\begin{tabular}{ll}
\hline Parameter & Weightage \\
\hline pH & 0.08 \\
EC & 0.61 \\
SSP & 0.08 \\
RSC & 0.05 \\
SAR & 0.10 \\
Cl & 0.04 \\
No3 & 0.02 \\
So4 & 0.01 \\
B & 0.01 \\
\hline
\end{tabular}

Table 2: Suitability index of groundwater quality

\begin{tabular}{ll}
\hline Water quality index & Description \\
\hline $0-35$ & Unsuitable \\
$35-70$ & Moderate \\
$70-100$ & Suitable \\
\hline
\end{tabular}

Table 3: Statisticl characteristics of alkalinity and chemicals constituents of groundwater at Damghan plain

\begin{tabular}{llllllllllll}
\hline Wells & Well No & $\mathrm{Ca}^{+2}$ & $\mathrm{Mg}^{+2}$ & $\mathrm{Na}^{+}$ & $\mathrm{K}^{+}$ & $\mathrm{Hco}^{-}$ & $\mathrm{Cl}^{-}$ & $\mathrm{NO} 3-\mathrm{N}$ & $\mathrm{SO} 4-\mathrm{S}$ & $\mathrm{B}(\mathrm{mg} / \mathrm{l})$ & $\mathrm{PH}$ \\
\hline Mean & 1 to 24 & 4.88 & 1.129 & 8.97 & 0.18 & 7.0 & 7.91 & 3.66 & 2.94 & 0.25 & 7.86 \\
Max & 1 to24 & 6.0 & 2.30 & 16.0 & 0.34 & 8.75 & 14.4 & 5.0 & 7.6 & 0.8 & 8.3 \\
Min & 1to24 & 2.1 & 0.00 & 4.50 & 0.10 & 4.0 & 4.0 & 1.9 & 0.0 & 0.0 & 7.33 \\
SD & 1 to24 & 0.82 & 0.53 & 3.34 & 0.06 & 1.18 & 3.12 & 1.01 & 2.0 & 0.26 & 0.27 \\
\hline
\end{tabular}

Table 4: Quality classification of water based on different criteria for irrigation

\begin{tabular}{|c|c|c|c|c|c|c|c|}
\hline Wells & $\begin{array}{l}\text { Well } \\
\text { no }\end{array}$ & $\begin{array}{l}\text { TDS } \\
\text { value }\end{array}$ & $\begin{array}{l}\mathrm{EC}\left(\mu \mathrm{sm}^{-1}\right) \\
\text { value }\end{array}$ & $\begin{array}{l}\text { SAR } \\
\text { value }\end{array}$ & $\begin{array}{l}\text { SSP } \\
\text { value }\end{array}$ & $\begin{array}{l}\text { RSC } \\
\text { value }\end{array}$ & $\begin{array}{l}\text { Salinity, sodium } \\
\text { hazard class }\end{array}$ \\
\hline Abdia & 1 & 1177.60 & 1840.00 & 5.00 & 58.50 & 1.30 & C3S1 \\
\hline Shams Abad & 2 & 966.40 & 1510.00 & 5.13 & 56.90 & 0.60 & C3S1 \\
\hline Shams Abad & 3 & 1395.20 & 2180.00 & 7.61 & 68.11 & 1.45 & $\mathrm{C} 3 \mathrm{~S} 2$ \\
\hline Abir Abad & 4 & 4000.00 & 6250.00 & 7.50 & 66.50 & 1.00 & $\mathrm{C} 4 \mathrm{~S} 2$ \\
\hline Gani Abad & 5 & 1840.60 & 2876.00 & 5.00 & 58.39 & 0.70 & $\mathrm{C} 4 \mathrm{~S} 2$ \\
\hline Hasnie & 6 & 1836.80 & 2870.00 & 2.97 & 46.11 & 0.30 & C4S1 \\
\hline Abd Abad & 7 & 1904.00 & 2975.00 & 6.00 & 64.75 & 2.30 & $\mathrm{C} 4 \mathrm{~S} 2$ \\
\hline Shaman & 8 & 972.80 & 1520.00 & 5.43 & 61.75 & 1.80 & $\mathrm{C} 3 \mathrm{~S} 2$ \\
\hline Nasr Abad & 9 & 1171.20 & 1830.00 & 2.69 & 43.98 & 0.40 & C3S1 \\
\hline Abd Abad & 10 & 1184.00 & 1850.00 & 2.94 & 43.65 & 0.00 & C3S1 \\
\hline berom & 11 & 2240.00 & 3500.00 & 5.37 & 59.92 & 1.30 & $\mathrm{C} 4 \mathrm{~S} 2$ \\
\hline Abas Abad & 12 & 2192.00 & 3425.00 & 8.37 & 69.63 & 0.80 & $\mathrm{C} 4 \mathrm{~S} 2$ \\
\hline Shaman & 13 & 4672.00 & 7300.00 & 7.10 & 65.26 & 1.30 & $\mathrm{C} 4 \mathrm{~S} 2$ \\
\hline Abas Abad & 14 & 1024.00 & 1600.00 & 5.74 & 50.20 & 2.40 & C3S1 \\
\hline Shaman & 15 & 2816.00 & 4400.00 & 5.61 & 59.28 & 0.50 & $\mathrm{C} 4 \mathrm{~S} 2$ \\
\hline Shaman & 16 & 4591.36 & 7174.00 & 5.78 & 61.90 & 2.00 & $\mathrm{C} 4 \mathrm{~S} 2$ \\
\hline Shaman & 17 & 4480.00 & 7000.00 & 4.62 & 56.21 & 1.90 & $\mathrm{C} 4 \mathrm{~S} 2$ \\
\hline Abas Abad & 18 & 3904.00 & 6100.00 & 5.10 & 60.69 & 1.00 & $\mathrm{C} 4 \mathrm{~S} 2$ \\
\hline Saeed Abad & 19 & 1152.00 & 1800.00 & 3.33 & 52.10 & 0.80 & C3S1 \\
\hline Abas Abad & 20 & 3968.00 & 6200.00 & 6.87 & 63.90 & 0.70 & $\mathrm{C} 4 \mathrm{~S} 2$ \\
\hline Shaman & 21 & 1164.80 & 1820.00 & 4.81 & 55.55 & 0.80 & C 3 S 1 \\
\hline Amin Abad & 22 & 1740.80 & 2720.00 & 2.92 & 45.17 & 0.60 & C4S1 \\
\hline Amin Abad & 23 & 2694.40 & 4210.00 & 2.87 & 44.52 & 0.40 & C4S1 \\
\hline Amin Abad & 24 & 1849.60 & 2890.00 & 3.90 & 59.20 & 0.70 & C4S1 \\
\hline Max & - & 4672.00 & 7300.00 & 8.37 & 69.63 & 2.40 & \\
\hline Min & - & 966.40 & 1510.00 & 2.69 & 43.65 & 0.00 & \\
\hline Mean & - & 2289.06 & 3576.66 & 5.11 & 57.17 & 1.04 & \\
\hline SD & - & 1281.00 & 2002.00 & 1.63 & 7.98 & 0.64 & \\
\hline
\end{tabular}

Note: TDS: Total Dissolved Solids; EC: Electrical Conductance, SAR: Sodium Adsorption Ratio, SSP: Soluble Sodium Percentage, RSC:

Residual Sodium Carbonate 


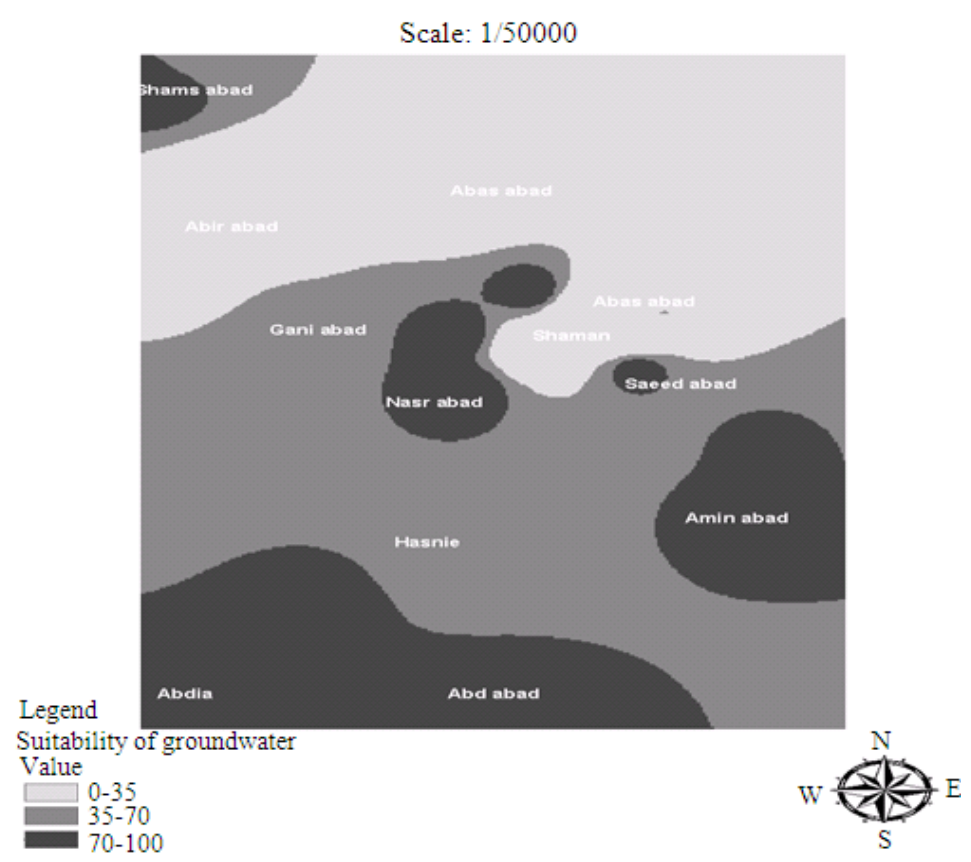

Fig. 1: The map of Suitability index of groundwater in damghan plain

Table 5: Relationship between water quality factors

\begin{tabular}{lllllll}
\hline Parameter & $\mathrm{pH}$ & $\mathrm{EC}$ & $\mathrm{TDS}$ & $\mathrm{SAR}$ & $\mathrm{SSP}$ & $\mathrm{RSC}$ \\
\hline PH & - & & & & & \\
EC & 0.27 & - & & & & \\
TDS & 0.27 & 0.98 & - & & & \\
SAR & 0.36 & 0.35 & 0.34 & - & & \\
SSP & 0.31 & 0.39 & 0.36 & 0.9 & - & \\
RSC & -0.06 & 0.18 & 0.15 & 0.47 & 0.44 & - \\
\hline
\end{tabular}

All of the SSP values were found from 43.65 69.63, that the highest SSP value related to Abas Abad village and the lowest value related to Nasr Abad village. Based on RSC criterion all groundwater samples were 0-2.4 (Table 4).The highest RSC value related to Abas Abad village and the lowest value related to Abd Abad village.

Ionic balance: While checking the correctness of the chemical analyses of these water samples, the differences between sum total of cations and anions were less than $5 \%$. The inter relationships among $\mathrm{pH}$, EC, TDS, SAR, SSP and RSC were determined in terms of correlation coefficient (Table 5). It was observed that SSP was strongly correlated with SAR, RSC and EC that had the correlation coefficient value of $0.9,0.44$ and 0.39 , respectively.

\section{DISCUSSION}

An analysis of the nature and rate of land use change and its associated impact on groundwater quality is essential for a proper understanding of the present environmental problems (Krishna et al., 2001). In this study, Suitability index is calculated to determine the suitability of water for irrigation purpose. Suitability index values revealed that the ground water in Amin Abad, Abdi, Abd Abad, Nasr Abad and parts of Shams Abad villages of study area were "Suitable" quality with the Suitability index range between 75-100 and therefore can be used for irrigation usage. Suitability index of the groundwater on Hasnie, Gani Abad and parts of Shams Abad villages were "Moderate" quality with the range between 35-70 and Abas Abad, Abir Abad and Shaman were "unsuitable" quality and cannot be used for irrigation purposes. The Suitability index map is shown in Fig. 1.

The results of this study indicates that parameters of groundwater such as ECw, SARw, chloride ,sodium mainly affect on the groundwater quality and crops growth in the study areas. The Suitability map of the groundwater indicates the presence about $36.4 \%$ of the groundwater lie in "unsuitable", $38.8 \%$ "Moderate" and 24.8\% "Suitable" class for irrigation purpose (Fig. 1). The observed low Suitability Index of the groundwater quality is because of location of near the desert and due to lack of deficiency water and rainfall and the plentiful use of water resources, dug of deep and semi-deep well is increased. In this study, high $\mathrm{pH}$, possibly due to the presence of considerable amount of sodium, calcium, magnesium, bicarbonate ions. 


\section{CONCLUSION}

It is also helpful for public to understand the quality of water as well as being a useful tool in many ways in the field of water quality management (Yisa and Jimoh, 2010). The present study demonstrated high efficiency for GIS to analyze complex spatial data. An different component and data should be incorporated into GIS applications to determine to a groundwater suitability (Tjandra et al., 2003). With an adequate database, Geographic Information Systems (GIS) can serve as a powerful analytic and decision-making tool for agriculture development (Arsalan, 2004).

The GIS would help to apply the groundwater management practices such as; proper groundwater resource management in terms of groundwater quality and quantity. In the present study salinity and $\mathrm{Cl}^{-}$and $\mathrm{HCO}^{3-}$ were the problems on irrigation water in some studying areas. This study showed that groundwater were categorized into" C3S1, C3S2, C4S1 and C4S2" class indicating high-very high salinity and low-medium alkali hazard (Table 1). According to Clesceri et al. (1989), the differences between sum total of cations and anions were less than 5\%. The inter relationships among $\mathrm{pH}, \mathrm{EC}$, TDS, SAR, SSP and RSC were determined in terms of correlation coefficient (Table 2). In respect of all evaluating criteria, villages of study areas that had "Suitable" and "Moderate" quality could safely be used for long-term irrigation purposes.

\section{REFERENCES}

APHA, AWWA, WPCF, 1998. Standard Methods for the Examination of Water and Wastewater. 20th Ed., American Public Health Association, Washington, DC, New York, USA. www.pdf4me.net/.../apha-standard-methods-waterand-wastewater.php

Arsalan, M.H., 2004. A GIS appraisal of Heavy metals concentration in Soil. GIS @ Development. Published by the American Society of Civil Engineers, 345 East 47 Street, New York, pp: 10017-2398.

www.gisdevelopment.net/magazine/gisdev/2004/a pril/heavymetals.shtml

Ashraf, S., H. Afshari, R. Munokyan and A. Ebadi, 2010. Multicriteria land suitability evaluation for barley by using GIS in Damghan plain. J. Food, Agric. Environ., 8: 626-628. http://www.worldfood.net/scientficjournal/2010 /issue3/abstracts/abstract113.php

Ayers, R.S., 1994. Water quality for agriculture. University of California Davis, California, USA,
Food and Agriculture Organization of the United Nations Rome, FAO. www.fao.org/DOCREP/003/T0234E/T0234E00.H TM

Bauder, J. W. and T.A. Brock. 2001. Irrigation water quality, soil amendment and crop effects on sodium leaching. Arid Land Res. Manage., 15:101113

waterquality.montana.edu/docs/qualityissues/sodiu m_leaching.shtml

Clesceri, L.S., A.E. Greenberg and R.R. Trussell, 1989. Standard Methods for the Examination of Water and Waste Water. 17th Edn., American Public Health Association, Washington DC., USA., pp: 1-175. www.umass.edu/tei/mwwp/acrobat/sm2510Bcondu ctivity.PDF

Eaton, A.D., L.S. Clesceri, E.W. Rice, A.E. Greenberg, M.A.H. Franson. 2005. Standard Methods for the Examination of Water and Wastewater: Centennial Edition. 21st Edn., American Public Health Association. Washington, D.C., ISBN: 0875530478 , pp: 1368.

Esmail, A.S., S.A. Rahim, W.W.Y. Zuhairi, F. Alshaebi and F.A. Nozaily, 2009. Assessment of groundwater and surface water pollution at mitm area, IBB city, Yemen. Am. J. Applied Sci., 6: 772-783. DOI: 10.3844/ajassp.2009.772.783

Ganapathy, C. and A. Ernest, 2004. Water quality assessement using web based GIS and distributed database management systems. Environ. Inform. Arch., 2: 938-945. www.iseis.org/eia/pdfstart.asp?no=04094

Hakim, M.A. A.S. Juraimi, M. Begum, M. Hasanuzzaman and M.K. Uddin et al., 2009. Suitability evaluation of groundwater for irrigation, drinking and industrial purposes. Am. J. Environ. Sci., 5: 413419. DOI: 10.3844/ajessp.2009.413.419

Karimipour, F., M. Delavar and M. Kianie, 2004. Water quality management using GIS data mining. Environ. Inform. Arch., 2: 946-954. www.iseis.org/jei/fulltext.asp?no=200500047

Krishna, N.D.R., A.K. Maji, Y.V.N. Krishna and B.P.S. Rao, 2001. Remote sensing and geographical information system for canopy cover mapping. J. Ind. Soc. Remote Sens., 29: 108-113. www.springerlink.com/index/8444J55637Q371W3 .pdf

Orebiyi, E.O., J.A. Awomeso, O.A. Idowu , O. Martins and O. Oguntoke et al., 2010. Assessment of pollution hazards of shallow well water in abeokuta and environs, Southwest, Nigeria. Am. J. Environ. Sci., 6: 50-56. www.thescipub.com/abstract/10.3844/ajessp.2010. 50.56 
Ramakrishnaiah, C.R., C. Adashiv and G. Ranganna. 2009. Assessment of Water Quality Index for the Groundwater in Tumkur Taluk, Karnataka State, India. E-J. Chem., 6: 523-530. www.ejournals.in/PDF/V6N2/523-530.pdf

Tank, D.K. and C.P.S. Chandel, 2009. A hydrochemical elucidation of the groundwater composition under domestic and irrigated land in Jaipur City. Environ. Monit. Assess, 166: 69-77. DOI: 10.1007/s10661009-0985-7

www.ncbi.nlm.nih.gov/pubmed/19479331
Tjandra, F.L., A. Kondhoh, M. Aslam, 2003. A conceptual database design for hydrology using GIS. Proceedings of Asia Pacific Association of Hydrology and Water Resources., 13-15, Kyoto, Japan. www.igu.in/14-2/1\%20goyal.pdf

Yisa, J. and T. Jimoh, 2010. Analytical studies on water quality index of river landzu, Am. J. Applied Sci., 7: 453-458.

www.scipub.org/fulltext/ajas/ajas74453-458.pdf 